\title{
High expression of HMGB1 in children with refractory Mycoplasma pneumoniae pneumonia
}

\author{
Ying Ding ${ }^{1 \dagger}$, Chu Chu ${ }^{1 \dagger}$, Yuqin $\mathrm{Li}^{1}$, Gen Li ${ }^{1}$, Xiaoli Lei ${ }^{1}$, Weifang Zhou ${ }^{1 *}$ (D) and Zhengrong Chen ${ }^{2^{*}}$
}

\begin{abstract}
Background: Increasing numbers of refractory or severe, even fatal, cases of Mycoplasma pneumoniae infections have been reported in recent years. Excessive inflammatory responses play a vital role in the pathogenesis of refractory M. pneumoniae pneumonia (RMPP). HMGB1 is an actively secreted cytokine produced by macrophages and other inflammatory cells that participates in various infectious diseases. The present study aimed to explore the role and clinical significance of HMGB1 in children with RMPP and the potential mechanism of HMGB1 expression.
\end{abstract}

Methods: Four hundred and fifty-two children diagnosed with M. pneumoniae pneumonia, including 108 children with RMPP, were enrolled from January 2013 to December 2015 at the Children's Hospital of Soochow University. HMGB1, TNF-a, and IL-6 in peripheral blood from RMPP and non-RMPP (NRMPP) cases were detected by real-time PCR and ELISA. Lipid-associated membrane proteins (LAMPs) were extracted from live M. pneumoniae and prepared at different concentrations for stimulation of THP-1 cells. After coculture with LAMPs, HMGB1, TNF-a, IL-6, RAGE, TLR2, and TLR4 in THP-1 cells were detected by real-time PCR.

Results: Occurrences of cough, fever, and abnormal lung signs were more frequent in RMPP cases compared with NRMPP cases (all $p<0.05$ ). Children with RMPP had longer hospital stays than children with NRMPP $(p<0.05)$. Different distributions of lymphocytes were noted between RMPP and NRMPP cases. HMGB1, TNF-a, and IL-6 levels were significantly higher in RMPP cases compared with NRMPP cases (all $p<0.05$ ). HMGB1 had good diagnostic ability to differentiate RMPP with AUC of 0.876 , sensitivity of 0.833 , and specificity of 0.824 compared with TNF-a and IL-6. HMGB1 expression in THP-1 cells was increased by stimulation with $10 \mu \mathrm{g} / \mathrm{ml}$ LAMPs. TLR2 expression was increased after stimulation with $6 \mu \mathrm{g} / \mathrm{ml}$ LAMPs. HMGB1 level was positively associated with TNF-a, IL-6, and TLR2 levels.

Conclusions: HMGB1 is a good diagnostic biomarker for differentiating RMPP and NRMPP. LAMPs from M. pneumoniae may induce HMGB1 expression in immune cells through the TLR2 pathway. Further in vitro and in vivo studies are needed for the development of a new treatment strategy to inhibit the HMGB1 pathway, thereby preventing the inflammation in RMPP.

Keywords: HMGB1, M. Pneumoniae pneumonia, Lipid-associated membrane proteins (LAMPs), RMPP

\footnotetext{
*Correspondence: zwf_1969@163.com; chen_zheng_rong@163.com

${ }^{\dagger}$ Ying Ding and Chu Chu contributed equally to this work.

'Department of Infectious Disease, Children's Hospital of Soochow University,

Suzhou 215003, China

${ }^{2}$ Department of Respiratory Disease, Children's Hospital of Soochow

University, Suzhou 215003, China
}

(c) The Author(s). 2018 Open Access This article is distributed under the terms of the Creative Commons Attribution 4.0 International License (http://creativecommons.org/licenses/by/4.0/), which permits unrestricted use, distribution, and reproduction in any medium, provided you give appropriate credit to the original author(s) and the source, provide a link to the Creative Commons license, and indicate if changes were made. The Creative Commons Public Domain Dedication waiver (http://creativecommons.org/publicdomain/zero/1.0/) applies to the data made available in this article, unless otherwise stated. 


\section{Background}

Pneumonia is one of the most serious infectious diseases, with high morbidity and mortality. In 2015, pneumonia killed an estimated 922,000 children under 5 years of age, accounting for $15 \%$ of all child deaths. Mycoplasma pneumoniae is a major bacterial pathogen of the airways that causes acute and chronic infections of the respiratory tract and accounts for approximately 10$40 \%$ of all lower respiratory tract infections including community-acquired pneumonia (CAP) [1, 2]. Children under 5 years of age usually suffer from mild upper respiratory symptoms, while older children and adolescents develop bronchopneumonia and require hospitalization [3].

Several mechanisms, including intracellular localization, direct cytotoxicity, and inflammation response activation through Toll-like receptors (TLRs) leading to pro-inflammatory cytokine-mediated tissue injury, play essential roles in the pathogenesis of pneumonia [4-6]. The symptoms of M. pneumoniae pneumonia (MPP) are correlated with the induction of pro-inflammatory cytokines [7]. Excessive inflammatory responses induced by $M$. pneumoniae play vital roles in the pathogenesis of CAP including refractory $M$. pneumoniae pneumonia (RMPP) [8].

RMPP presents with clinical and radiological deterioration despite macrolide antibiotic therapy for $\geq 7$ days [9], and can develop into severe life-threatening pneumonia. IL-10 and IFN- $\gamma$ may have important roles in RMPP [10].

The mechanism for the excessive inflammatory responses in RMPP has not been fully elucidated. High-mobility group box protein 1 (HMGB1) is an actively secreted cytokine produced by macrophages and other inflammatory cells during innate immune responses to invasion [11]. Like other members of the pro-inflammatory cytokine family, biologically active HMGB1 can be expressed on the plasma membrane or released by activated inflammatory cells to accumulate in vivo during infection. HMGB1 is related to epithelial barrier destruction, organ dysfunction, and even death through its activation of immunocompetent cells to produce some pro-inflammatory factors (such as TNF- $\alpha$, IL-1) [12]. A previous study demonstrated that surfactant protein-A can inhibit mycoplasma-induced dendritic cell maturation through regulation of HMGB1 cytokine activity to minimize lung inflammation [13]. Thus, HMGB1 may play a role in the inflammatory responses during $M$. pneumoniae infection. To our knowledge, there are no reports on HMGB1 expression in children with RMPP.

The present study aimed to explore the role and clinical significance of HMGB1 in children with RMPP or non-RMPP (NRMPP) and the potential mechanism of HMGB1 expression, and to provide new clues for MPP prevention and treatment.

\section{Methods}

\section{Patients}

Children diagnosed with CAP were enrolled from January 2013 to December 2015 in the Children's Hospital of Soochow University. The age range was 1 month to 14 years. All patients underwent chest radiography and M. pneumoniae tests including specific IgM in peripheral blood by ELISA and specific DNA fragments in nasopharyngeal aspirates by real-time PCR. The exclusion criteria for the study were: (1) patients with congenital heart diseases, hereditary metabolic diseases, neurological disorders, bronchopulmonary dysplasia, and immunodeficiency; (2) patients co-infected with other pathogens.

Finally, a total of 452 hospitalized children with MPP on the basis of either specific IgM in a blood test or positive PCR result combined with chest radiography and physical examination [14] were enrolled during the study period. All of the chest radiographs were reviewed by an experienced radiologist. Data for clinical manifestations and laboratory tests during the disease course were obtained. RMPP cases were defined as those showing clinical and radiological deterioration despite appropriate antibiotic therapy for $\geq 7$ days [9]. Twenty-four children who underwent selective surgery were chosen as healthy controls. The study was approved by the Institutional Review Board of the Children's Hospital of Soochow University.

\section{Serology of $M$. pneumoniae}

Specific antibodies against $M$. pneumoniae (IgM and IgG) were detected in serum samples from the children during the acute phase (upon admission) and convalescent phase (upon discharge) using a commercial ELISA kit (Shenzen YHLO Biotech, Shenzhen, China) according to the manufacturer's instructions. Acute $M$. pneumoniae infection was defined as either a single positive serum IgM titer (cut-off $1.1 \mathrm{~S} / \mathrm{CO}$ ) or a 4-fold increase in IgG titer (cut-off $24 \mathrm{RU} / \mathrm{mL}$ ) in the convalescent serum sample.

\section{Real-time PCR for M. pneumoniae detection}

A real-time PCR procedure (Daan Gene Co. Ltd., Guangzhou, China), which was approved by the State Food and Drug Administration of China, was used to detect $M$. pneumoniae in real time [15]. Briefly, one sample of nasopharyngeal aspirate was shaken for $30 \mathrm{~s}$ and centrifuged at $15,000 \times g$ for $5 \mathrm{~min}$. The sediment was collected and DNA was extracted from a 400- $\mu \mathrm{l}$ aliquot in accordance with the manufacturer's instructions. PCR amplification was performed using primers and probes purchased from Daan Gene Co. Ltd. in a 7600 real-time PCR system (Applied Biosystems, Foster City, CA, USA). The PCR conditions were as follows: $93{ }^{\circ} \mathrm{C}$ 
for $2 \mathrm{~min}$; 10 cycles of $93{ }^{\circ} \mathrm{C}$ for $45 \mathrm{~s}$ and $55{ }^{\circ} \mathrm{C}$ for $60 \mathrm{~s}$; 30 cycles of $93{ }^{\circ} \mathrm{C}$ for $30 \mathrm{~s}$ and $55^{\circ} \mathrm{C}$ for $45 \mathrm{~s}$. Quantitative curves were drawn with standard control samples at several concentrations. M. pneumoniae-positive samples were defined as those with DNA concentrations exceeding $2.5 \times 10^{3}$ copies $/ \mathrm{ml}$ to exclude $M$. pneumoniae colonization.

\section{Detection of TNF- $a$ and IL- 6 by ELISA}

Peripheral blood was collected on admission and the plasma supernatant was stored at $-70{ }^{\circ} \mathrm{C}$ after centrifugation. TNF- $\alpha$ and IL-6 ELISA kits were purchased from Multi Science Company. All procedures were conducted according to the manufacturer's instructions.

\section{Preparation of lipid-associated membrane proteins (LAMPs) from M. pneumoniae}

M. pneumoniae strain M129 was purchased from the Institute of Pathogen Biology (Medical College of University of South China). M. pneumoniae was grown in SP4 broth for $72 \mathrm{~h}$ at $37^{\circ} \mathrm{C}$, centrifuged at $10,000 \times g$ for $20 \mathrm{~min}$, resuspended in saline to yield $1 \times 10^{8} \mathrm{CFU} /$ $50 \mu \mathrm{l}$, and frozen at $-80{ }^{\circ} \mathrm{C}$ until extraction of LAMPs. Briefly, the $M$. pneumoniae pellet was suspended in Tris-buffered saline containing $1 \mathrm{mM}$ EDTA (TBSE), solubilized by addition of Triton X-114 to a final concentration of $2 \%$, and incubated at $4{ }^{\circ} \mathrm{C}$ for $1 \mathrm{~h}$. The lysate was then incubated at $37{ }^{\circ} \mathrm{C}$ for $10 \mathrm{~min}$ for phase separation. After centrifugation at $10,000 \times g$ for $20 \mathrm{~min}$, the upper aqueous phase was removed and replaced with the same volume of TBSE. The phase separation procedure was repeated twice. The final Triton X-114 phase was resuspended in TBSE to the original volume, and 2.5 volumes of ethanol were added to precipitate membrane components after overnight incubation at $20{ }^{\circ} \mathrm{C}$. After centrifugation, the pellet was suspended in phosphate-buffered saline and sonicated for $30 \mathrm{~s}$ at output 5 (Sonics, USA). The protein concentration of the final suspension was measured with the Coomassie Protein Assay Regent (Pierce, Rockford, IL, USA).

\section{THP-1 cell stimulation by LAMPs in vitro}

The human monocytic cell line THP-1 was purchased from ATCC (Manassas, VA, USA). THP-1 cells were cultured in RPMI 1640 medium containing 10\% fetal calf serum (Wisent, Nanjing, China), $2 \mathrm{mM}$ l-glutamine, $100 \mathrm{U} / \mathrm{ml}$ penicillin $\mathrm{G}$, and $100 \mu \mathrm{g} / \mathrm{ml}$ streptomycin. The cell density was adjusted to $1 \times 10^{6}$ cells $/ \mathrm{ml}$ in 24 -well plates. The cells were then cultured with different doses of LAMPs $(0,2,4,6,8$, and $10 \mu \mathrm{g} / \mathrm{ml})$ for $16 \mathrm{~h}$. The cells were harvested and immediately stored at $-80{ }^{\circ} \mathrm{C}$ until further analysis.
HMGB1, TNF-a, IL-6, RAGE, TLR2, and TLR4 detection by real-time PCR

Peripheral blood mononuclear cells from children with M. pneumoniae infection or freshly isolated THP-1 cells in culture were collected and lysed with Trizol (Invitrogen, Carlsbad, CA, USA). Total RNA was extracted using an RNeasy Mini Kit (Qiagen, Valencia, CA, USA). A total mixture of $15 \mu \mathrm{l}$ containing $2 \mu \mathrm{g}$ RNA, $25 \mu \mathrm{M}$ random hexamers (Sangon Biotech, Shanghai, China), and RNase-free water was prepared for cDNA synthesis at $37{ }^{\circ} \mathrm{C}$ according to the manufacturer's instructions. PCR amplifications were performed in a volume of $20 \mu \mathrm{l}$ containing $1 \mu \mathrm{l}$ cDNA, $10 \mu \mathrm{l}$ primers, and probes (Table 1). The PCR conditions were as follows: 40 cycles of $95{ }^{\circ} \mathrm{C}$ for $30 \mathrm{~s}, 95{ }^{\circ} \mathrm{C}$ for $3 \mathrm{~s}$, and $57{ }^{\circ} \mathrm{C}$ for $20 \mathrm{~s}$. The gene expression was assessed by the comparative cycle threshold $(\mathrm{Ct})$ method. The relative amounts of mRNA for the TLRs were determined by subtracting the $\mathrm{Ct}$ values for these genes from the $\mathrm{Ct}$ value for the housekeeping gene GAPDH $(\Delta \mathrm{Ct})$. The amounts of mRNA were expressed relative to the amount of GAPDH mRNA $\left(2^{-\Delta \Delta C t}\right)$ and presented as means \pm SEM.

\section{Statistical analysis}

Continuous variables were compared by Student's $t$-test or the Mann-Whitney $U$ test if the clinical or laboratory data had a non-normal distribution. Categorical data were analyzed by the chi-square test. For in vitro studies, statistical significance was determined by one-way ANOVA, followed by the Tukey-Kramer test. Correlations between HMGB1 and other inflammatory factors were evaluated by Spearman's rank correlation. Data were expressed as means \pm SD if data had a normal distribution.

\section{Results}

Demographic data and clinical characteristics in children with RMPP or NRMPP

In total, 108 cases were defined as RMPP and 344 cases were NRMPP. As shown in Table 2, the RMPP cases had a higher mean age $(62.55 \pm 35.05$ months $)$ than the

Table 1 Foward and reverse primers using for real-time PCRs

\begin{tabular}{lll}
\hline & Foward $\left(5^{\prime} \rightarrow 3^{\prime}\right)$ & Reverse $\left(5^{\prime} \rightarrow 3^{\prime}\right)$ \\
\hline TNF-a & CAACCTCTTCTGGCTCAA & TGGTGGTCTTGTTGCTTA \\
HMGB1 & TGTAAGGCTGTGTAAGATT & AAGGTTAGTGGCTATTGAA \\
IL-6 & ACCTCAGATTGTTGTTTT & TAGTGTCCTAACGCTCATA \\
RAGE & CAATGAACAGGAATGGAA & AGAGGCAGAATCTACAAT \\
TLR2 & TGAGGAACTTGAGATTGAT & CACGGAACTTGTAACATC \\
TLR4 & TCAGTGTGCTTGTAGTAT & CCTGGCTTGAGTAGATAA \\
GAPDH & CTCTGGTAAAGTGGATATTGT & GGTGGAATCATATTGGAACA \\
\hline
\end{tabular}

HMGB1 High Mobility Group Box Protein 1, TNF tumor necrosis factor, IL interleukin, RAGE receptor for advanced glycation endproducts, TLR toll-like receptors, GAPDH glyceraldehyde phosphate dehydrogenase 
Table 2 Comparison of demographic data and clinical characteristics between RMPP and NRMPP

\begin{tabular}{llll}
\hline & $\begin{array}{l}\text { NRMPP } \\
(n=344)\end{array}$ & $\begin{array}{l}\text { RMPP } \\
(n=108)\end{array}$ & $p$ value \\
\hline Age (month) & $35.78 \pm 27.38$ & $62.55 \pm 35.05$ & $<0.001$ \\
Male (\%) & $198(57.6)$ & $54(50)$ & 0.185 \\
Clinical profiles & & & \\
Cough (\%) & $311(90.4)$ & $108(100)$ & $<0.001$ \\
Wheezing (\%) & $120(34.9)$ & $14(13.0)$ & $<0.001$ \\
Nose running (\%) & $121(35.2)$ & $40(37.0)$ & 0.731 \\
Fever (day) & $3.39 \pm 2.47$ & $9.18 \pm 3.55$ & $<0.001$ \\
Difficult feeding (\%) & $12(3.5)$ & $2(1.9)$ & 0.530 \\
Diarrhea (\%) & $31(9.0)$ & $9(8.3)$ & 1.000 \\
Abnormal signs of lungs (\%) & $169(49.1)$ & $81(75.0)$ & $<0.001$ \\
Hospital stay (day) & $5.97 \pm 0.99$ & $11.04 \pm 2.72$ & $<0.001$ \\
\hline
\end{tabular}

RMPP refractory Mycoplasma pneumoniae pneumonia, NRMPP non-refractory Mycoplasma pneumoniae pneumonia

NRMPP cases ( $35.78 \pm 27.38$ months). The occurrences of cough, fever, and abnormal lung signs were more frequent in RMPP cases compared with NRMPP cases (all $p<0.05$ ). However, wheezing was more common in NRMPP cases compared with RMPP cases $(p<0.05)$. Children with RMPP had longer hospital stays than children with NRMPP $(p<0.05)$.

The laboratory test data for children with RMPP and NRMPP are shown in Table 3. Total white blood cells, absolute neutrophils, C-reactive protein, IgA, IgG, and IgM in peripheral blood were significantly higher in RMPP cases compared with NRMPP cases. High LDH and CK levels were more frequent in children with RMPP. Different distributions of lymphocytes were noted between RMPP and NRMPP cases (Table 3).

\section{Comparison of HMGB1, TNF- $a$, and IL- 6 levels between RMPP and NRMPP cases}

As shown in Fig. 1, the median TNF- $\alpha$ concentration was $50.96 \mathrm{pg} / \mathrm{ml}$ in RMPP cases and $42.78 \mathrm{pg} / \mathrm{ml}$ in NRMPP cases, the median IL-6 concentration was $39.82 \mathrm{pg} / \mathrm{ml}$ in RMPP cases and $34.65 \mathrm{pg} / \mathrm{ml}$ in NRMPP cases, and the median HMGB1 concentration was $7.44 \times 10^{-3}$ in RMPP cases and $4.35 \times 10^{-3}$ in NRMPP cases. The HMGB1, TNF- $\alpha$, and IL- 6 levels were significantly higher in RMPP cases compared with NRMPP cases (all $p<0.05$ ). Compared with healthy controls, no differences were found in HMGB1 levers for NRMPP cases, while higher TNF- $\alpha$ and IL-6 levels were found in NRMPP cases.

Durations of fever and hospital stay were two major factors associated with disease severity. Thus, we analyzed the correlations between HMGB1, TNF- $\alpha$, and IL-6 levels and these two major factors. As shown in Fig. 2, HMGB1, TNF- $\alpha$, and IL- 6 levels were positively correlated with duration of fever or hospital stay.
Table 3 Comparison of laboratory tests between RMPP and NRMPP cases

\begin{tabular}{llll}
\hline & $\begin{array}{l}\text { NRMPP } \\
(n=344)\end{array}$ & $\begin{array}{l}\text { RMPP } \\
(n=108)\end{array}$ & $p$ value \\
\hline WBC $\left(\times 10^{9} / \mathrm{L}\right)$ & $8.67 \pm 3.72$ & $10.28 \pm 4.33$ & $<0.001$ \\
Absolute neutrophils $\left(\times 10^{9} / \mathrm{L}\right)$ & $4.20 \pm 2.70$ & $6.32 \pm 3.59$ & $<0.001$ \\
Platelets $\left(\times 10^{9} / \mathrm{L}\right)$ & $312.03 \pm 109.95$ & $322.65 \pm 90.8$ & 0.363 \\
CRP $(\mathrm{mg} / \mathrm{L})$ & $7.06 \pm 7.00$ & $36.08 \pm 30.81$ & $<0.001$ \\
High level of $\mathrm{LDH}(>382 \mathrm{U} / \mathrm{L}, \%)$ & $164(47.7)$ & $64(59.3)$ & 0.153 \\
High level of $\mathrm{CK}(>225 \mathrm{U} / \mathrm{L}, \%)$ & $14(4.1)$ & $21(19.4)$ & $<0.001$ \\
IgA $(\mathrm{g} / \mathrm{L})$ & $0.64 \pm 0.52$ & $1.25 \pm 0.80$ & $<0.001$ \\
IgG $(\mathrm{g} / \mathrm{L})$ & $7.25 \pm 2.36$ & $9.16 \pm 3.03$ & $<0.001$ \\
IgM(g/L) & $1.28 \pm 0.55$ & $1.72 \pm 0.82$ & $<0.001$ \\
Lymphocytes distribution & & & \\
CD3+ $\left(\times 10^{9} / \mathrm{L}\right)$ & $2.34 \pm 1.68$ & $2.00 \pm 1.05$ & 0.047 \\
$\mathrm{CD} 3+\mathrm{CD} 4+\left(\times 10^{9} / \mathrm{L}\right)$ & $1.36 \pm 1.06$ & $1.08 \pm 0.64$ & 0.008 \\
$\mathrm{CD} 3-\mathrm{CD} 8+\left(\times 10^{9} / \mathrm{L}\right)$ & $0.82 \pm 0.65$ & $0.82 \pm 0.44$ & 0.990 \\
$\mathrm{CD} 4 / \mathrm{CD} 8$ & $1.74 \pm 0.73$ & $1.35 \pm 0.43$ & $<0.001$ \\
$\mathrm{CD} 3-\mathrm{CD} 19+\left(\times 10^{9} / \mathrm{L}\right)$ & $0.97 \pm 0.85$ & $0.66 \pm 0.56$ & $<0.001$ \\
$\mathrm{CD} 3-\mathrm{CD}(16+56+)\left(\times 10^{9} / \mathrm{L}\right)$ & $0.44 \pm 0.36$ & $0.37 \pm 0.26$ & 0.047 \\
$\mathrm{CD} 19+\mathrm{CD} 23+\left(\times 10^{9} / \mathrm{L}\right)$ & $0.51 \pm 0.48$ & $0.34 \pm 0.31$ & 0.001 \\
\hline RMPP & & &
\end{tabular}

RMPP refractory Mycoplasma pneumoniae pneumonia, NRMPP non-refractory Mycoplasma pneumoniae pneumonia, CRP C-reative protein, $L D H$ lactate dehydrogenase, $C K$ creatine kinase, $C D$ cluster of differentiation

There were interactions among HMGB1, TNF- $\alpha$, and IL-6. HMGB1 and IL- 6 were both correlated with TNF- $\alpha$ ( $r=0.395, p=0.002$ and $r=0.268, p=0.042$, respectively). Thus, the associations were further analyzed by linear regression using a stepwise procedure to exclude an interaction effect. Only HMGB1 was associated with duration of fever ( $\beta=0.451, p=0.0004)$, while only TNF- $\alpha$ was associated with duration of hospital stay $(\beta=0.469, p=0.0002)$.

\section{Diagnostic values of HMGB1, TNF- $a$, and IL- 6 in children with RMPP}

To estimate the diagnostic abilities of HMGB1, TNF- $\alpha$, and IL-6 in children with RMPP, a receiver-operating characteristic analysis was performed. As shown in Fig. 3, HMGB1 had good diagnostic ability for differentiation of RMPP with cut-off of $5.25 \times 10^{-3}$, AUC of 0.876 , Sig. of AUC of $0.779-0.973$, and Youden index of 0.657 compared with TNF- $\alpha$ and IL-6.

\section{Expression of HMGB1 in THP-1 cells stimulated by LAMPs extracted from $M$. pneumoniae}

In present study, expression of HMGB1 in THP-1 increased after stimulated with $10 \mu \mathrm{g} / \mathrm{ml}$ LAMPs as well as TNF- $\alpha$ with $2 \mu \mathrm{g} / \mathrm{ml}$ and IL- 6 with $4 \mu \mathrm{g} / \mathrm{ml}$. There were also dose-dependent changes in TNF- $\alpha$ and IL- 6 expression. RAGE and TLR2 expression was increased after stimulation with $8 \mu \mathrm{g} / \mathrm{ml}$ LAMPs and $6 \mu \mathrm{g} / \mathrm{ml}$ LAMPs, 

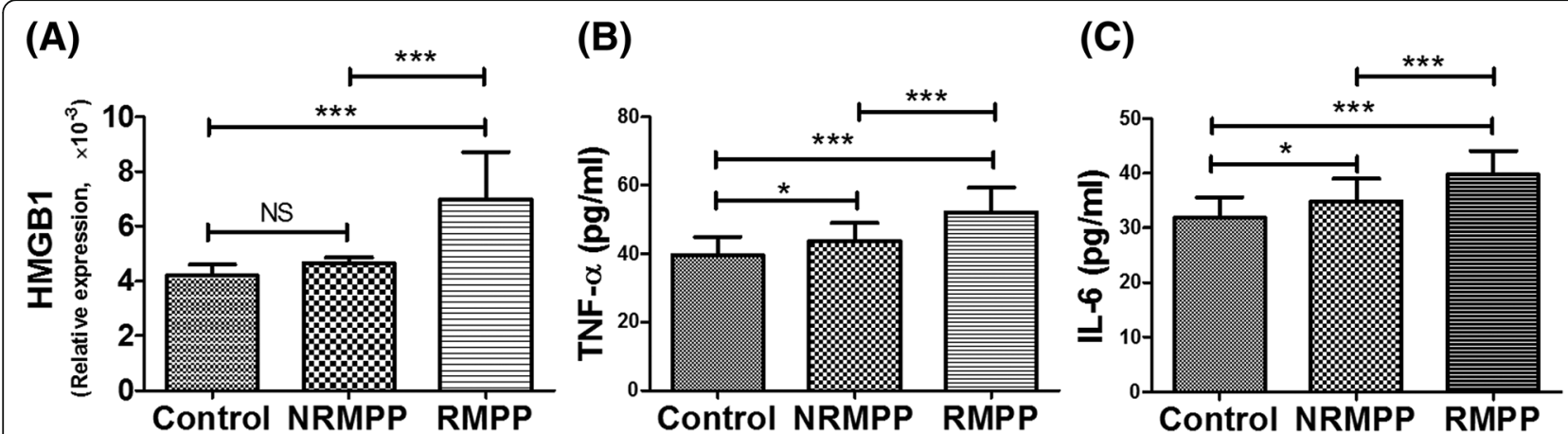

Fig. 1 HMGB1, TNF-a, IL-6 levels in children with RMPP or NRMPP. (a) Comparison of HMGB1 between RMPP and NRMPP; (b) Comparison of TNF-a between RMPP and NRMPP; (c) Comparison of IL-6 between RMPP and NRMPP. * RMPP: refractory Mycoplasma pneumoniae pneumonia; NRMPP: non-refractory Mycoplasma pneumoniae pneumonia. ${ }^{*} p<0.05 ;{ }^{* * *} p<0.001$

respectively. No difference in TLR4 expression was found after stimulation with LAMPs (Fig. 4).

We also analyzed the correlations between HMGB1 and other inflammatory factors in THP-1 cells stimulated by LAMPs. As shown in Table 4, HMGB1 level was positively associated with TNF- $\alpha$, IL-6, and TLR2 levels.

\section{Discussion}

Increasing numbers of refractory or severe, even fatal, cases of $M$. pneumoniae infections have been reported in recent years $[10,16]$, although $M$. pneumoniae infection was traditionally considered to be self-limiting. In the present study, children with RMPP had longer durations of hospital stay and fever as well as high levels of LDH, a useful marker for initiation of steroid therapy [17].
A recent study demonstrated that macrolide-resistant $M$. pneumoniae can lead to clinically refractory pneumonia, showing no clinical or radiological response to macrolides, and further progress to severe and complicated pneumonia [18]. However, the prevalence of macrolide-resistant MPP has rapidly increased, especially in Asian countries, recently reaching $80-90 \%$ of cases. In the Suzhou area, the prevalence of macrolide-resistant $M$. pneumoniae accounts for 92.5\% of cases (data not shown). Thus, macrolide resistance may be not the main reason for the development of RMPP in children.

Many studies have suggested that excessive inflammatory responses play important roles in $\operatorname{RMPP}[8,10]$. HMGB1 participates in the pathogenesis of inflammatory diseases and mediates immune responses that range

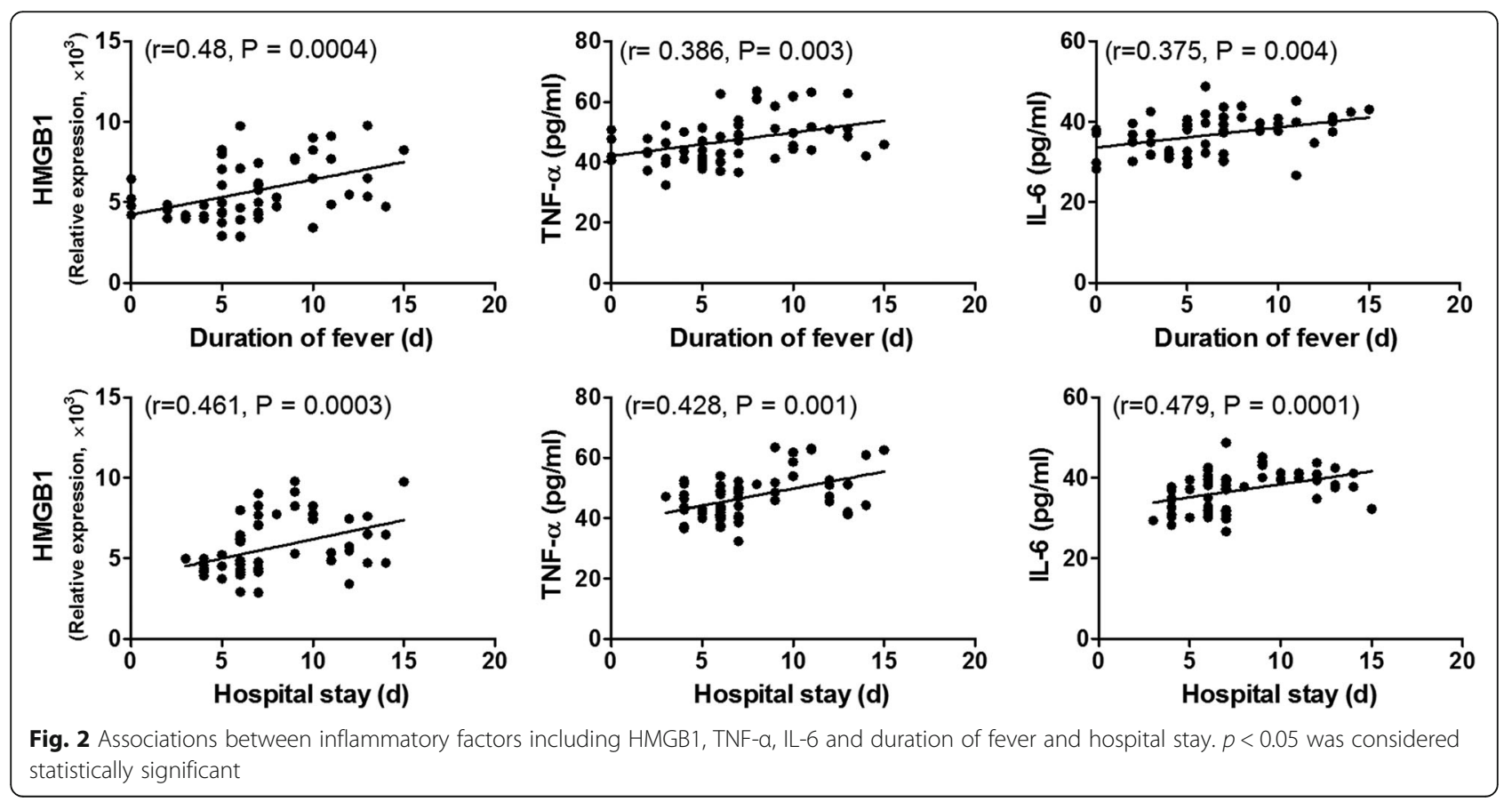




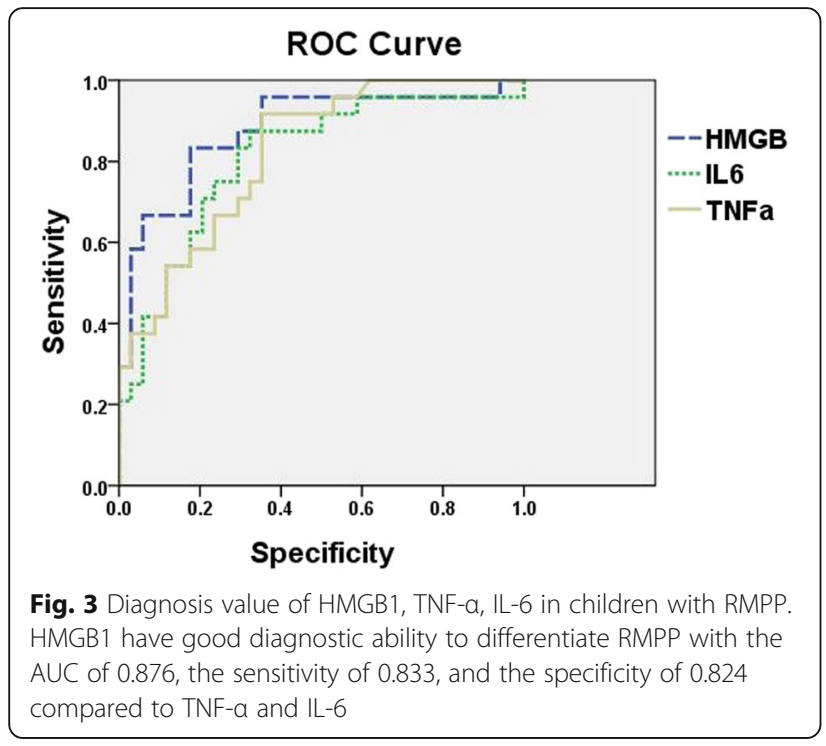

from inflammation and bacterial killing to tissue repair [19]. HMGB1 is associated with divergent clinical conditions such as sepsis [20]. HMGB1 initiates and perpetuates immune responses during infections. A recent study indicated that RSV infection of human airway epithelial cells induces a significant release of HMGB1, which subsequently triggers immune responses by activating primary human monocytes [21]. To our knowledge, there are no reports on HMGB1 expression in children with M. pneumoniae infection. We found that children with RMPP had higher HMGB1 levels than children with NRMPP and that HMGB1 had good diagnostic ability to differentiate between RMPP and NRMPP.

TNF- $\alpha$ is mainly produced by monocytes and macrophages, and is a multifunctional peptide with biological
Table 4 Correlations between expression of HMGB1 and other inflammatory factors

\begin{tabular}{lll}
\hline Parameters & \multicolumn{2}{l}{ HMGB1 (relative expression) } \\
\cline { 2 - 3 } & $\mathrm{r}$ & $\mathrm{P}$ \\
\hline TNF-a $(\mathrm{pg} / \mathrm{ml})$ & 0.7544 & 0.0003 \\
IL-6 (pg/ml) & 0.7709 & 0.0002 \\
RAGE (relative expression) & 0.2755 & 0.2684 \\
TLR2 (relative expression) & 0.6932 & 0.0014 \\
TLR4 (relative expression) & -0.22303 & 0.3737 \\
\hline
\end{tabular}

HMGB1 High Mobility Group Box Protein 1, TNF tumor necrosis factor, IL interleukin, RAGE receptor for advanced glycation endproducts, $T L R$ toll-like receptors

activity. TNF- $\alpha$ participates in the lung injury associated with severe pneumonia [22-24]. The TNF- $\alpha$ expression level in children with MPP was significantly higher than that in healthy children. The mechanism is to increase the level of TNF- $\alpha$ in immune cells such as monocytes, macrophages and adhesion receptors after MPP infection, Which is suggested that TNF- $\alpha$ is involved in the pathogenesis of MPP. Wang et al. [8] showed that serum TNF- $\alpha$ levels in children with RMPP were significantly higher than those in children with NRMPP, which was confirmed in a mouse model of MPP infection [25]. The increase in IL-6 was the earliest infection index. IL-6 is an important cytokine in the MPP inflammatory responses. It also has a vital role in the early stage of the immune response [26]. When mycoplasma infection occurs, macrophages produce TNF- $\alpha$ to increase the inflammatory response. By inducing differentiation of $\mathrm{T}$ cells, thereby stimulating mononuclear macrophages and lymphocytes to produce IL- 6 and other cytokines, the serum concentrations of IL- 6 and TNF- $\alpha$ are increased

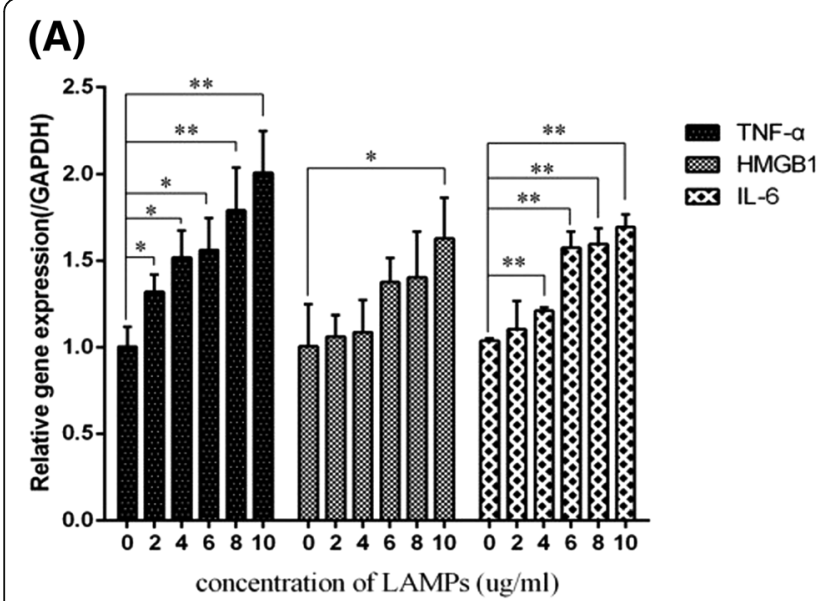

(B)

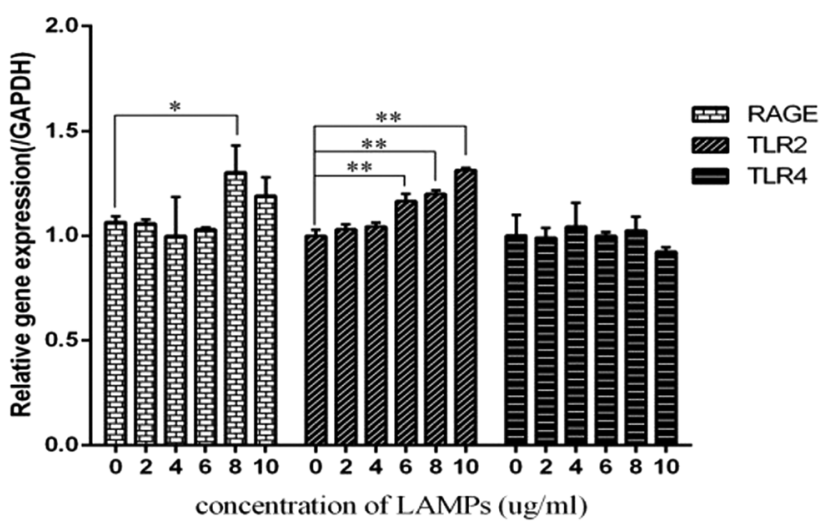

Fig. 4 THP-1 cells stimulated by LAMPs extracted from M. pneumoniae. THP-1 cells were cultured in RPMI 1640 containing $10 \%$ FCS, 2 mM I-glutamine, $100 \mathrm{U} / \mathrm{ml}$ penicillin $\mathrm{G}$, and $100 \mathrm{\mu g} / \mathrm{ml}$ streptomycin. The cell concentration of THP-1 was adjusted to $1 \times 10^{6} \mathrm{ml}$ in $24-w e l l$ plates. Different doses of LAMPs $(0 \mu \mathrm{g} / \mathrm{ml}, 2 \mu \mathrm{g} / \mathrm{ml}, 4 \mu \mathrm{g} / \mathrm{ml}, 6 \mu \mathrm{g} / \mathrm{ml}, 8 \mu \mathrm{g} / \mathrm{ml}$ and $10 \mu \mathrm{g} / \mathrm{ml})$ were co-cultured with THP-1 cells for 16 h. (a) Expression of HMGB1, TNF-a, IL-6 induced by LAMPs; (b) Expression of RAGE, TLR2, TLR4 induced by LAMPs. Data are shown as mean \pm SEM of 3 independent experiments. * $p<0.05$; ** $p<0.01$ 
[22]. Studies have shown that cytokines such as IL-6 are associated with the severity of MPP [27].

LAMPs extracted from M. pneumoniae can stimulate THP-1 or pulmonary epithelial cells to induce inflammatory responses including production of IL-6, IL-8, and heme oxygenase- 1 in vitro $[28,29]$. Meanwhile, the inflammatory responses induced by $M$. pneumoniae were shown to be associated with pathogen-associated molecular patterns (PAMPs) such as TLR2 and TLR4 [30]. RAGE, a member of the immunoglobulin superfamily of cell surface molecules, is expressed on monocytes and binds to and transduces the signals stimulated by HMGB1. There are no reports on the expression of HMGB1 and its association with other inflammatory factors in THP-1 cells after stimulation with LAMPs. In the present study, it was demonstrated that LAMPs from $M$. pneumoniae could induce HMGB1 expression in THP-1 cells. Meanwhile, HMGB1 was correlated with TNF- $\alpha$, IL-6, and TLR2. Activation and expression of HMGB1 occur when monocytes or macrophages are exposed to microbe-associated PAMPs such as TLR2 and endogenously-derived inflammatory mediators including TNF- $\alpha$, IL-1, and IFN- $\gamma$ [12]. Lipoproteins derived from $M$. pneumoniae can activate NF-kb through TLR2 [31]. Accordingly, we presume that LAMPs enhanced the expression of HMGB1 in THP-1 cells through TLR2. In addition, HMGB1 secreted by monocytes or macrophages can stimulate these cells to release pro-inflammatory cytokines including TNF- $\alpha$ and IL-6 [32]. Further studies are needed to clarify the mechanism of the inflammatory responses induced by HMGB1 .

This article describes a prospective study to investigate the expressions of TNF- $\alpha$, IL-6, and HMGB1 in children with MPP. TNF- $\alpha$ and IL- 6 are pro-inflammatory factors. In previous studies on HMGB1, TNF- $\alpha$ and IL- 6 were often used for reference and comparison with HMGB1, especially in studies on sepsis. The study by van Zoelen et al. [33] showed that the serum HMGB1 levels in patients with severe pneumonia were significantly higher than healthy controls, suggesting that HMGB1 is involved in the development of pneumonia. However, HMGB1 has not been reported in patients with MPP. In the literature, HMGB1 was mostly detected by PCR, while ELISA was used by a small number of research groups. The present study is the only research at the cellular level, which is also a deficiency of the study.

\section{Conclusions}

The HMGB1 level in peripheral blood is increased in children with RMPP and is a good diagnostic biomarker for differentiating RMPP and NRMPP. LAMPs from M. pneumoniae may induce HMGB1 expression in immune cells through the TLR2 pathway. Further studies in vitro and in vivo are needed for the development of a new treatment strategy to inhibit the HMGB1 pathway, thereby preventing the inflammation in RMPP.

\section{Abbreviations}

CAP: Community-acquired pneumonia; HMGB1: High-mobility group box protein 1; LAMPs: Lipid-associated membrane proteins; NRMPP: Non refractory Mycoplasma pneumoniae pneumonia; RMPP: Refractory Mycoplasma pneumoniae pneumonia; TLRs: Toll-like receptors

\section{Acknowledgments}

We gratefully acknowledge the valuable cooperation of Mrs. Anwei Xie and the members of her team in helping us accomplish collecting peripheral blood and we thank Alison Sherwin, PhD, from Liwen Bianji, Edanz Group China

(www.liwenbianji.cn/ac) for editing the English text of a draft of this manuscript.

\section{Funding}

The design of the study, collection and analysis of data in this study was supported by the National Natural Science Foundation of China [Zhengrong Chen, grant number 81771676], Jiangsu Provincial Medical Youth Talent [Zhengrong Chen, grant number QNRC2016766] and Science and

Technology Projects of Suzhou [Zhengrong Chen, grant number SS201869]. The interpretation of data and manuscript preparation in this study and the publication fee was supported by Science and Technology Projects of Suzhou sanitary bureau [Weifang Zhou, grant number SS201535].

\section{Availability of data and materials}

The datasets generated during and/or analysed during the current study are available from the corresponding author on reasonable request.

\section{Authors' contributions}

YD and CC wrote the main manuscript text; YL, GL and XL collected andanalyzed clinical data; ZC and WZ are to take responsibility for study design. All authors reviewed the manuscript. All authors read and approved the final manuscript.

\section{Ethics approval and consent to participate}

All procedures performed in studies involving human participants were in accordance with the ethical standards of the Institutional Review Board of Children's Hospital of Soochow University (project approval number 2012LW002) and with the 1964 Helsinki declaration and its later amendments or comparable ethical standards. Participant consent was written by the adults or the legal representatives of patients aged $<16$ years and informed consent forms were archived.

\section{Consent for publication}

Not applicable.

\section{Competing interests}

The authors declare that they have no competing interests.

\section{Publisher's Note}

Springer Nature remains neutral with regard to jurisdictional claims in published maps and institutional affiliations.

Received: 28 November 2017 Accepted: 20 August 2018 Published online: 29 August 2018

\section{References}

1. Ngeow YF, Suwanjutha S, Chantarojanasriri T, Wang F, Saniel M, Alejandria $M$, et al. An Asian study on the prevalence of atypical respiratory pathogens in community-acquired pneumonia. Int J Infect Dis. 2005;9:144-53.

2. Meyer Sauteur PM, Jacobs BC, Spuesens EB, Jacobs E, Nadal D, Vink C, et al. Antibody responses to Mycoplasma pneumoniae: role in pathogenesis and diagnosis of encephalitis? PLoS Pathog. 2014;10:e1003983.

3. Waites KB, Talkington DF. Mycoplasma pneumoniae and its role as a human pathogen. Clin Microbiol Rev. 2004;17:697-728.

4. Seto S, Kenri T, Tomiyama T, Miyata M. Involvement of P1 adhesin in gliding motility of Mycoplasma pneumoniae as revealed by the inhibitory effects of antibody under optimized gliding conditions. J Bacteriol. 2005;187:1875-7.

5. Arai S, Furukawa M, Munakata T, Kuwano K, Inoue H, Miyazaki T. Enhancement of cytotoxicity of active macrophages by mycoplasma: role of mycoplasma-associated induction of tumor necrosis factor-alpha (TNFalpha) in macrophages. Microbiol Immunol. 1990;34(3):231-43. 
6. Wang Y, Liu S, Li Y, Wang Q, Shao J, Chen Y, et al. Mycoplasma bovisderived lipid-associated membrane proteins activate IL-1 $\beta$ production through the NF-kB pathway via toll-like receptor 2 and MyD88. Dev Comp Immunol. 2016:55:111-8.

7. Salvatore CM, Fonseca-Aten M, Katz-Gaynor K, Gomez AM, Mejias A, Somers $C$, et al. Respiratory tract infection with Mycoplasma pneumoniae in interleukin-12 knockout mice results in improved bacterial clearance and reduced pulmonary inflammation. Infect Immun. 2007;75(1):236-42.

8. Wang M, Wang Y, Yan Y, Zhu C, Huang L, Shao X, et al. Clinical and laboratory profiles of refractory Mycoplasma pneumoniae pneumonia in children. Int J Infect Dis. 2014;29:18-23.

9. Tamura A, Matsubara K, Tanaka T, Nigami H, Yura K, Fukaya T. Methylprednisolone pulse therapy for refractory Mycoplasma pneumoniae pneumonia in children. J Inf Secur. 2008;57(3):223-8.

10. Zhang Y, Mei S, Zhou Y, Huang M, Dong G, Chen Z. Cytokines as the good predictors of refractory Mycoplasma pneumoniae pneumonia in school-aged children. Sci Rep. 2016;6:37037.

11. Wang H, Bloom O, Zhang M, Vishnubhakat JM, Ombrellino M, Che J, et al. HMGB-1 as a late mediator of endotoxin lethality in mice. Science. 1999;285: 248-51.

12. Andersson U, Tracey KJ. HMGB1 is a therapeutic target for sterile inflammation and infection. Annu Rev Immunol. 2011;29:139-62.

13. Ledford JG, Lo B, Kislan MM, Thomas JM, Evans K, Cain DW, et al. Surfactant protein-a inhibits mycoplasma-induced dendritic cell maturation through regulation of HMGB-1 cytokine activity. J Immunol. 2010;185(7):3884-94.

14. Mclntosh K. Community-acquired pneumonia in children. N Engl J Med. 2002;346(6):429-37.

15. Yan $Y$, Wei $Y$, Jiang $W$, Hao C. The clinical characteristics of corticosteroidresistant refractory Mycoplasma pneumoniae pneumonia in children. Sci Rep. 2016;6:39929.

16. Miyashita N, Narita M, Tanaka T, Akaike H, Teranishi H, Oishi T, et al. Histological findings in severe Mycoplasma pneumoniae pneumonia. J Med Microbiol 2017;66(5):690-2

17. Miyashita N, Kawai $\mathrm{Y}$, Inamura N, Tanaka T, Akaike $\mathrm{H}$, Teranishi $\mathrm{H}$, et al. Setting a standard for the initiation of steroid therapy in refractory or severe Mycoplasma pneumoniae pneumonia in adolescents and adults. J Infect Chemother. 2015 Mar;21(3):153-60.

18. Yang HJ, Song DJ, Shim JY. Mechanism of resistance acquisition and treatment of macrolide-resistant Mycoplasma pneumoniae pneumonia in children. Korean J Pediatr. 2017;60(6):167-74.

19. Yang H, Wang H, Chavan SS, Andersson U. High mobility group box protein 1 (HMGB1): the prototypical endogenous danger molecule. Mol Med. 2015; 21(Suppl 1):S6-S12.

20. Lee IC, Kim DY, Bae JS. Sulforaphane Reduces HMGB1-Mediated Septic Responses and Improves Survival Rate in Septic Mice. Am J Chin Med. 2017:1-19.

21. Hosakote YM, Brasier AR, Casola A, Garofalo RP, Kurosky A. Respiratory syncytial virus infection triggers epithelial HMGB1 release as a damageassociated molecular pattern promoting a Monocytic inflammatory response. J Virol. 2016;90(21):9618-31.

22. Llibre JM, Urban A, Garcia E, et al. Bronchiolitis obliterans organizing pneumonia associated with acute Mycoplasma pneumoniae infection[J] ClinInfect Dis. 2013;30(6):1340-2.

23. Radisic M, Torn A, Gutierrez P, et al. Severe acute lung injury caused by Mgcoplasma pneumoniae: potential role for steroid pulses in treatment[J]. Clin Infect Dis. 2012;33(6):1507-11.

24. Kazachkow MY, Hu PC, Carson JL, et al. Release of cytokines by human nasal epithelial cells and peripheral blood mononuclear cells infected with mycoplasma pneumoniae[J]. Exp Biol Med. 2013;232(5):330-5.

25. Hsia BJ, Ledford JG, Potts-Kant EN, et al. Mast cell TNF receptors regulate responses to mycoplasma pneumoniae in surfactant protein a (SP-A)-/_ mice[J]. J Allergy Clin Immunol. 2012;130(1):205-14.

26. Tsujimoto H, Takahata R, Nomura S, et al. Predictive value of pleural and serum interleukin-6 levels for pneumonia and hypo-oxygenations after esophageetomy[J]. J Surg Res. 2013;182(2):e61.

27. Hsieh CC, Tang RB, Tsai CH, et al. Serum interleukin-6 and tumor necrosis factor-alpha concentrations in children with mycoplasma pneumonia[J]. Microbiol Immunol Infect. 2001;34(2):109-12.

28. Hu J, Chen C, Ou G, You X, Tan T, Hu X, et al. Nrf2 regulates the inflammatory response, including heme oxygenase-1 induction, by Mycoplasma pneumoniae lipid-associated membrane proteins in THP-1 cells. Pathog Dis. 2017;75(4):44.
29. Choi SY, Lim JW, Shimizu T, Kuwano K, Kim JM, Kim H. Reactive oxygen species mediate Jak2/Stat3 activation and IL-8 expression in pulmonary epithelial cells stimulated with lipid-associated membrane proteins from Mycoplasma pneumoniae. Inflamm Res. 2012;61(5):493-501.

30. Shimizu T. Inflammation-inducing factors of Mycoplasma pneumoniae. Front Microbiol. 2016;7:414.

31. Shimizu T, Kida Y, Kuwano K. Triacylated lipoproteins derived from Mycoplasma pneumoniae activate nuclear factor-kappaB through toll-like receptors 1 and 2. Immunology. 2007;121(4):473-83.

32. Andersson U, Wang H, Palmblad K, Aveberger AC, Bloom O, ErlandssonHarris $\mathrm{H}$, et al. High mobility group 1 protein $(\mathrm{HMG}-1)$ stimulates proinflammatory cytokine synthesis in human monocytes. J Exp Med. 2000; 192(4):565-70.

33. Van Zoelen MA, Laterre PF, van Veen SQ, et al. Systemic and local high mobility group box 1 concentrations during severe infection[J]. Crit Care Med. 2007;35(12):2799-804

\section{Ready to submit your research? Choose BMC and benefit from:}

- fast, convenient online submission

- thorough peer review by experienced researchers in your field

- rapid publication on acceptance

- support for research data, including large and complex data types

- gold Open Access which fosters wider collaboration and increased citations

- maximum visibility for your research: over $100 \mathrm{M}$ website views per year

At BMC, research is always in progress.

Learn more biomedcentral.com/submissions 